\title{
Interleukin 1 Stimulates Its Own Receptor Expression on Human Fibroblasts through the Endogenous Production of Prostaglandin(s)
}

\author{
Tohru Akahoshi, Joost J. Oppenheim, and Kouji Matsushima \\ Laboratory of Molecular Immunoregulation, Biological Response Modifiers Program, Division of Cancer Treatment, \\ National Cancer Institute, Frederick, Maryland 21701-1013
}

\begin{abstract}
The regulation of interleukin 1 receptor (IL 1R) expression on human dermal fibroblasts was investigated. On exposure to IL 1 for $3 \mathrm{~h}$ at $37^{\circ} \mathrm{C}$, the capacity of fibroblasts to bind ${ }^{125} \mathrm{I}$-labeled human recombinant IL 1 alpha $\left({ }^{125}\right.$ I-IL $\left.1 \alpha\right)$ was reduced by 75\%. The IL 1 binding capability of the fibroblasts was restored to control levels by $16 \mathrm{~h}$ after removal of unbound IL 1 , and then increased to about twofold over that of control cells by $48 \mathrm{~h}$. This later enhancement of IL 1 receptor expression after IL 1 treatment was abolished by indomethacin. Addition of exogenous (PGE 1 and $\mathrm{PGE}_{2}$, also analogues of $\mathrm{AMP}$, or forskolin increased the specific binding of ${ }^{125} \mathrm{I}-\mathrm{IL} 1 \alpha$ to fibroblasts. Scatchard analysis indicated that $\mathrm{PGE}_{2}$ increased the number of IL $1 \mathrm{R}$ from $\sim 1.6 \times 10^{3}$ to $5.4 \times 10^{3}$ per cell without change in the binding affinity. These data suggest that the later IL 1-induced up-regulation of IL $1 R$ is mediated by IL 1 stimulation of endogenous prostaglandin production. The combination of $\mathrm{PGE}_{2}$ and prednisolone increased the number of IL $1 R$ on fibroblasts in an additive manner.
\end{abstract}

\section{Introduction}

The availability of recombinant murine and human IL 1 has facilitated studies of the cell surface receptor for IL 1 on various responsive cells. Dower et al. first reported the expression of specific receptors for IL 1 on a variety of both human and murine cell types (1). We have also demonstrated the presence of high-affinity receptors for IL 1 on an EBV-transformed human B lymphocyte cell line and have shown that the receptors for IL $1 \alpha$ and IL $1 \beta$ are identical (2). The regulation of IL 1 receptor (IL-1R) expression on various cell types remains largely unexplored and provides a potentially crucial locus of control of IL 1 activity. We have reported that IL 1 rapidly down-regulates IL 1 receptor expression on the human large granular lymphocyte YT cell line (3). We have also demonstrated that glucocorticoid hormones (GC) markedly increased the number of IL 1 receptors on several cell types including human peripheral B lymphocytes, human dermal fibroblasts, and YT cells without alteration in the binding affinity (4).

Address reprint requests to Dr. Kouji Matsushima, Laboratory of Molecular Immunoregulation, BRMP, DCT, National Cancer Institute, Frederick Cancer Research Facility, Building 560, Room 31-19, Frederick, MD 21701-1013.

Received for publication 29 February 1988 and in revised form 19 April 1988

1. Abbreviations used in this paper: Act. D, actinomycin $\mathrm{D} ; \mathrm{CH}$, cycloheximide; GC, glucocorticoid hormones; IL IR, interleukin 1 receptor.

The Journal of Clinical Investigation, Inc.

Volume 82, October 1988, 1219-1224
In this study, we have similarly observed that IL 1 rapidly initially down-regulates IL 1 receptor expression on human dermal fibroblasts. However, thereafter, IL 1 up-regulates IL 1 receptor expression through IL-1-induced endogenous production of prostaglandin(s) on human dermal fibroblasts. Exogenously added $\mathrm{PGE}_{2}$ and prednisolone also enhanced IL $1 \mathrm{R}$ expression by fibroblasts and PBMC in an additive manner. Consequently, these data suggest that the in vivo expression of IL 1 receptors may be up-regulated both by prostaglandins and glucocorticoids that are produced in response to administration of IL 1.

\section{Methods}

Reagents. Prednisolone, $\mathrm{PGE}_{1}, \mathrm{PGE}_{2}, 8$-Bromoadenosine 3':5'-cyclic monophosphate (8-Br cAMP), $\mathrm{N}^{6}, 2^{\prime}-O$-dibutyryladenosine- $3^{\prime}: 5^{\prime}$-cyclic monophosphate (dibutyryl cAMP), $\mathrm{N}^{2}, \mathrm{O}^{2}$-dibutyryl guanosine- $3^{\prime}: 5^{\prime}$ cyclic monophosphoric acid (dibutyryl cGMP), and forskolin were purchased from Sigma Chemical Co. (St. Louis, MO). Cycloheximide $(\mathrm{CH})$ and actinomycin D (Act. D) were also obtained from Sigma Chemical Co. Purified, carrier-free human recombinant IL- $1 \alpha$ was a generous gift from Dr. M. Yamada (Dainippon Pharmaceutical Co., Osaka, Japan).

Cell culture. Human dermal fibroblasts (CRL 1507; American Type Culture Collection, Rockville, MD) were maintained in DME (Advanced Biotechnologies Inc., Silver Spring, MD) supplemented with 10\% FCS (Hyclone Laboratories, Logan, UT), $2 \mathrm{mM}$ of L-glutamine, $100 \mathrm{U} / \mathrm{ml}$ penicillin, and $100 \mu \mathrm{g} / \mathrm{ml}$ streptomycin at $37^{\circ} \mathrm{C}$ in $5 \%$ $\mathrm{CO}_{2}$. Fibroblasts $\left(7 \times 10^{5}\right.$ cells; passages 8-30) were plated in $35-\mathrm{mm}$ diam dishes (3506, Costar, Cambridge, MA) containing $3 \mathrm{ml}$ of medium. After $2 \mathrm{~d}$, the medium was replaced with $3 \mathrm{ml}$ of new medium at $37^{\circ} \mathrm{C}$ containing various reagents as described. Prostaglandins were dissolved in 95\% ethanol, forskolin was dissolved in DMSO, and cAMP was dissolved in Dulbecco's PBS and all were then added to the culture media to yield the indicated final concentration. An equivalent volume of ethanol or DMSO was added to control cultures. PBMC were freshly isolated by Ficoll-Hypaque gradient centrifugation and were resuspended at a density of $5 \times 10^{5}$ cells per $\mathrm{ml}$ in RPMI 1640 medium (Advanced Biotechnologies, Inc.) with $10 \%$ FCS.

Preparation of iodinated IL 1 . Human recombinant IL $1 \alpha$ was labeled with ${ }^{125} \mathrm{I}$ using the Bolton-Hunter reagent $(2,200 \mathrm{Ci} / \mathrm{mmol}$, monoiodinated; New England Nuclear, Boston, MA) for $1 \mathrm{~h}$ on ice as previously described (4). After stopping the reaction with $0.5 \mathrm{ml}$ of 0.5 $\mathrm{M}$ glycine in $0.1 \mathrm{M}$ borate buffer, $\mathrm{pH} 8.5,{ }^{125} \mathrm{I}-\mathrm{IL} 1 \alpha$ was separated from free iodine by chromatography on a Sephadex G-25 column (Pharmacia Fine Chemicals, Piscataway, NJ). The labeling efficiency of IL 1 was $\sim 5 \times 10^{7} \mathrm{cpm}$ of ${ }^{125} \mathrm{I} / \mu \mathrm{g}$ of IL $1 \alpha$.

Receptor binding assay. After treatment with various reagents, fibroblasts were transferred to $0.5 \mathrm{ml}$ of binding medium (DME supplemented with $1 \mathrm{mg} / \mathrm{ml} \mathrm{BSA}$ and $10 \mathrm{mM}$ Hepes buffer). ${ }^{125} \mathrm{I}-\mathrm{IL} 1 \alpha(14$ $\mathrm{ng} / \mathrm{ml}$ ) was incubated with cells in the presence or absence of unlabeled IL $1 \alpha$ at a concentration of $2 \mu \mathrm{g} / \mathrm{ml}$. After a $1-\mathrm{h}$ incubation at $4^{\circ} \mathrm{C}$, the cells were rinsed four times with cold DME and solubilized in $0.5 \mathrm{ml}$ of $0.1 \mathrm{~N} \mathrm{NaOH}$ containing $2 \% \mathrm{Na}_{2} \mathrm{HCO}_{3}$ and $1 \%$ SDS. The total cell-associated radioactivity was determined by counting this volume in a gamma counter. PBMC were harvested after treatment with various 
reagents, and the specific binding activity of ${ }^{125} \mathrm{I}-\mathrm{IL} 1 \alpha$ to PBMC was determined as described elsewhere (4).

Measurement of $P G E_{2}$ levels. $\mathrm{PGE}_{2}$ concentrations in culture media were determined by RIA using a PGE $_{2}{ }^{125}$ I-RIA kit (NEK 020A10; New England Nuclear).

Treatment with metabolic inhibitors. The cells were cultured with $3.5 \mu \mathrm{g} / \mathrm{ml} \mathrm{CH}$ or $1.5 \mu \mathrm{g} / \mathrm{ml}$ Act. D in the presence of prednisolone $\left(1 \times 10^{-6} \mathrm{M}\right)$ or $\mathrm{PGE}_{2}\left(1 \times 10^{-6} \mathrm{M}\right)$ or $8-\mathrm{Br}$ cAMP $\left(1 \times 10^{-3} \mathrm{M}\right)$. After $12 \mathrm{~h}$ of culture, the effects of the metabolic inhibitor on the induction of IL 1 receptor were measured. The viability of the treated cells was not changed as compared with the control cells as measured by trypan blue dye exclusion test.

\section{Results}

Biphasic effects of IL 1 on IL 1 receptor expression. We examined the effect of IL 1 on IL $1 R$ expression on normal human dermal fibroblasts. Fibroblasts in a confluent state were preincubated for $3 \mathrm{~h}$ at $37^{\circ} \mathrm{C}$ in the presence or absence of human recombinant IL $1 \alpha(100 \mathrm{U} / \mathrm{ml})$. The cells were washed extensively to remove unbound IL 1 , and were subsequently incubated in fresh medium at $37^{\circ} \mathrm{C}$. Fig. 1 demonstrates the total binding of ${ }^{125}$ I-IL $1 \alpha$ to fibroblasts at different times after IL 1 treatment. Under these conditions, IL 1 initially down-regulated IL $1 R$ on the surface of fibroblasts as observed in a human large granular lymphocyte cell line, YT cells, and other cell types $(3,5)$. In this study, pretreatment with $100 \mathrm{U} / \mathrm{ml} \mathrm{IL} 1$ $(5 \mathrm{ng})$ reduced the binding of ${ }^{125} \mathrm{I}$-IL $1 \alpha$ to fibroblasts by $75 \%$. The binding of labeled IL 1 recovered to $\sim 60 \%$ of control by $6 \mathrm{~h}$, and returned to control levels by 16-20 h. IL 1-untreated control cells showed moderately reduced binding after $24 \mathrm{~h}$ of incubation. The binding of ${ }^{125} \mathrm{I}$-IL $1 \alpha$ to IL 1 -pretreated cells progressively increased over control levels with 24 and $116 \%$ increases over control level at 30 and $48 \mathrm{~h}$, respectively, and returned to control levels by day 3 .

Because the enhancement of IL 1 binding occurred relatively slowly, it was hypothesized to be an indirect effect me-

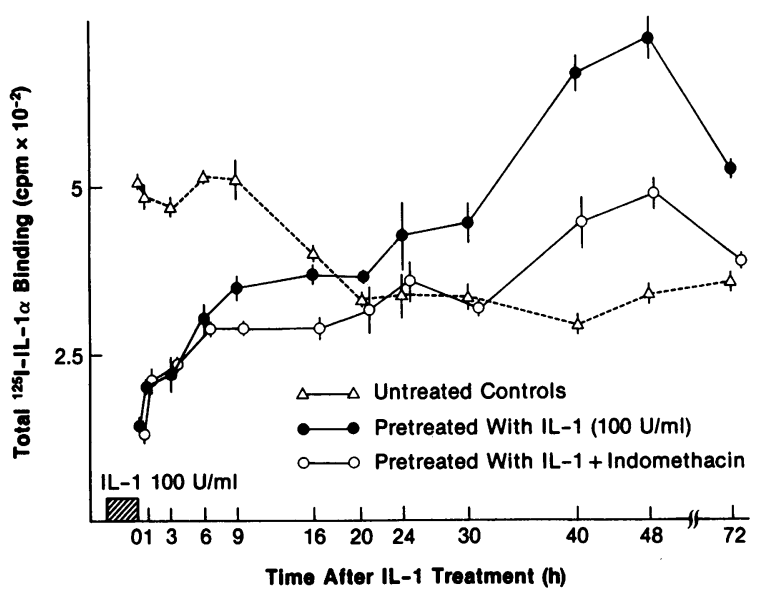

Figure 1. Biphasic effects of IL 1 on IL 1 R expression of fibroblasts. Human dermal fibroblasts (confluent state in $35-\mathrm{mm}$ culture dish) were pretreated with IL $1 \alpha(100 \mathrm{U} / \mathrm{ml})$ for $3 \mathrm{~h}$ at $37^{\circ} \mathrm{C}$ and washed to remove unbound IL 1 . Subsequently, the cells were incubated in fresh medium at $37^{\circ} \mathrm{C}$ with or without indomethacin $\left(2 \times 10^{-6} \mathrm{M}\right)$ for the indicated period. The specific binding of ${ }^{125} \mathrm{I}-\mathrm{IL} 1 \alpha$ to fibroblasts was determined as described in Methods. Each binding activity represents the mean (and indicated SD) of triplicate measurements. The data shown here represent three independent experiments. diated by the production(s) of such as prostaglandins by IL 1 -treated fibroblasts $(6,7)$. We therefore tested the effect of indomethacin on the restoration of IL $1 \mathrm{R}$ expression. Cells incubated with $2 \times 10^{-6} \mathrm{M}$ indomethacin after IL 1 pretreatment, showed reduced ${ }^{125} \mathrm{I}-\mathrm{IL} 1$ binding activity. Treatment with indomethacin largely inhibited the late phase of up-regulation of IL $1 R$ expression. Indomethacin itself did not decrease the IL 1 binding activity of control cells (data not shown). As shown in Table $I$, we also can demonstrate the production of $\mathrm{PGE}_{2}$ by fibroblasts in response to IL 1 and the block of $\mathrm{PGE}_{2}$ production by indomethacin. Under the condition of this experiment, the cell number and viability of down-regulated cells remained the same as for control cells (Table 1). These data suggest that the later IL 1-induced upregulation of IL $1 R$ is mediated by endogenous production of prostaglandins.

Effect of prostaglandins on specific ${ }^{125} I-I L ~ 1 \alpha$ binding. Human dermal fibroblasts were exposed to $\mathrm{PGE}_{2}\left(1 \times 10^{-6} \mathrm{M}\right)$ to determine the effect of exogenously added PGE on IL $1 R$ expression. Fig. 2 illustrates the mean of triplicate measurements of specific ${ }^{125} \mathrm{I}-\mathrm{IL} 1 \alpha$ binding at various times. The specific binding increased gradually with time after exposure to $\mathrm{PGE}_{2}$. The maximal effect appeared after 18-24 h of exposure, and thereafter binding declined toward control levels. Next fibroblasts were treated with different doses of $P G E_{1}$ and $P G E_{2}$ for 24 h. Fig. 3 demonstrates that $P \mathrm{CE}_{1}$ and $\mathrm{PGE}_{2}$ increased the binding of ${ }^{125} \mathrm{I}-\mathrm{IL} 1 \alpha$ in a dose-dependent manner. A concentration of $10^{-8} \mathrm{M}$ PGE (which can be produced by fibroblasts) augmented IL $1 \mathrm{R}$ expression significantly and maximal effects were obtained with $1 \times 10^{-7}-1 \times 10^{-6} \mathrm{M}$ of prostaglandins. Scatchard analysis was performed using fibroblasts treated with $\mathrm{PGE}_{2}\left(1 \times 10^{-6} \mathrm{M}\right)$ and prednisolone $\left(1 \times 10^{-6} \mathrm{M}\right)$ for $24 \mathrm{~h}$ to determine whether the increased binding could be accounted for by an increase in the number of high-affinity receptors. As illustrated in Fig. 4, treatment with $\mathrm{PGE}_{2}$ or another IL $1 \mathrm{R}$ up-regulator, prednisolone increased the number of ${ }^{125}$ I-IL $1 \alpha$ binding sites on fibroblasts without any alteration in binding affinity. Receptor numbers increased from 1.6 $\times 10^{3}$ by control cells, to $5.4 \times 10^{3}$ for $\mathrm{PGE}_{2}$ treated cells, and to $5.7 \times 10^{3}$ for prednisolone-treated cells. Fibroblasts treated with the combination of $\mathrm{PGE}_{2}\left(1 \times 10^{-6} \mathrm{M}\right)$ and prednisolone $\left(1 \times 10^{-6} \mathrm{M}\right)$, expressed $11 \times 10^{3}$ receptors per cell. There was no significant change in the binding affinity of control and treated cells $\left(4-6 \times 10^{-10} \mathrm{M}\right)$. Thus, $\mathrm{PGE}_{2}$ and $\mathrm{GC}$ both increased expression of high affinity receptors for IL 1 on fibroblasts, and the combination of $\mathrm{PGE}_{2}$ and $\mathrm{GC}$ had an additive effect on IL $1 \mathrm{R}$ expression.

Induction of $I L I R$ expression on $P B M C$ by $P G E_{2}$ and glucocorticoids. To determine whether $\mathrm{PGE}_{2}$ up-regulates IL $1 R$ on other cell types, $P B M C$ were exposed to $\mathrm{PGE}_{2}$ or prednisolone for $6 \mathrm{~h}$ at $37^{\circ} \mathrm{C}$. Cells were subsequently harvested and the specific binding activity of ${ }^{125}$ I-IL $1 \alpha$ was determined. As shown in Table II, both $\mathrm{PGE}_{2}$ and prednisolone also increased ${ }^{125} \mathrm{I}-\mathrm{IL}$ I $\alpha$ binding of PBMC as well as of fibroblasts. Indomethacin did not inhibit the induction of IL $1 R$ expression on PBMC by either exogenously added $\mathrm{PGE}_{2}$ or GC.

Induction of IL $1 R$ expression on fibroblasts by forskolin and $A M P$. As prostaglandins are known to stimulate adenylate cyclase, we examined the role of adenylate cyclase on IL $1 R$ expression on fibroblasts. Fibroblasts were treated for $24 \mathrm{~h}$ with different doses of forskolin, an activator of the catalytic subunit of adenylate cyclase (8). As shown in Fig. $5 A$, treat- 
Table I. Effect of IL 1 on IL 1 Receptor Expression, PGE Production, and Replication of Human Fibroblasts

\begin{tabular}{|c|c|c|c|c|}
\hline Pretreatment & Cultured for $48 \mathrm{~h}$ in & Cell number at $48 \mathrm{~h}$ & ${ }^{125}$ I-IL 1 bound & $\mathrm{PGE}_{2}$ in culture media \\
\hline & & $\times 10^{5} /$ well & $\mathrm{cpm} /$ well & $M$ \\
\hline None & MEM + 10\% FCS & $5.16 \pm 0.14$ & $433 \pm 23$ & $7.2 \times 10^{-10}$ \\
\hline IL $1(100 \mathrm{U} / \mathrm{ml})$ & $\mathrm{MEM}+10 \%$ FCS & $5.14 \pm 0.28$ & $735 \pm 37$ & $2.1 \times 10^{-8}$ \\
\hline IL $1(100 \mathrm{U} / \mathrm{ml})$ and indomethacin $\left(2 \times 10^{-6} \mathrm{M}\right)$ & $\begin{array}{l}\mathrm{MEM}+10 \% \mathrm{FCS}+2 \times 10^{-6} \mathrm{M} \\
\text { indomethacin }\end{array}$ & $5.27 \pm 0.35$ & $518 \pm 14$ & $1.9 \times 10^{-9}$ \\
\hline
\end{tabular}

Fibroblasts were cultured in conditions as described for Fig. 1.

ment with forskolin markedly enhanced the specific binding of ${ }^{125}$ I-IL $1 \alpha$ to fibroblasts in a dose-dependent manner, and maximal effects were obtained with $1 \times 10^{-5} \mathrm{M}$ of forskolin. We also evaluated the effect of analogues of CAMP on IL $1 R$ induction. Fibroblasts treated with high concentrations of dibutyryl cAMP or 8-Br cAMP $\left(1 \times 10^{-3} \mathrm{M}\right)$ for $24 \mathrm{~h}$ also showed augmentation of IL $1 \mathrm{R}$ expression (Fig. $5 \mathrm{~B}$ ). In contrast, dibutyryl cGMP did not increase specific binding of labeled IL $1 \alpha$ to fibroblasts. The combination of prednisolone with either forskolin or CAMP analogues also increased IL $1 R$ expression in an additive manner (data not shown). These data suggest that prostaglandins-induced up-regulation of IL $1 R$ expression was mediated by adenylate cyclase and accumulation of intracellular cAMP.

Effect of metabolic inhibitors on prostaglandin and glucocorticoid-induced IL $I R$ expression. To determine whether prostaglandins- and GC-induced IL $1 \mathrm{R}$ expression required de novo synthesis of new receptor, we analyzed the effects of metabolic inhibitors, $\mathrm{CH}$, and Act. D. Fibroblasts were treated with $3.5 \mu \mathrm{g} / \mathrm{ml} \mathrm{CH}$ or $1 \mu \mathrm{g} / \mathrm{ml}$ Act. D in the presence or absence of prednisolone $\left(1 \times 10^{-6} \mathrm{M}\right)$, $\mathrm{PGE}_{2}\left(10^{-6} \mathrm{M}\right)$, or $8-\mathrm{Br}$ $\operatorname{cAMP}\left(1 \times 10^{-3} \mathrm{M}\right)$ for $12 \mathrm{~h}$. These metabolic inhibitors abolished the up-regulation of IL $1 \mathrm{R}$ expression without reducing cell viability over a 12 -h period (Fig. 6). These data suggest that prostaglandins- and GC-induced IL IR up-regulation required both protein and RNA synthesis.

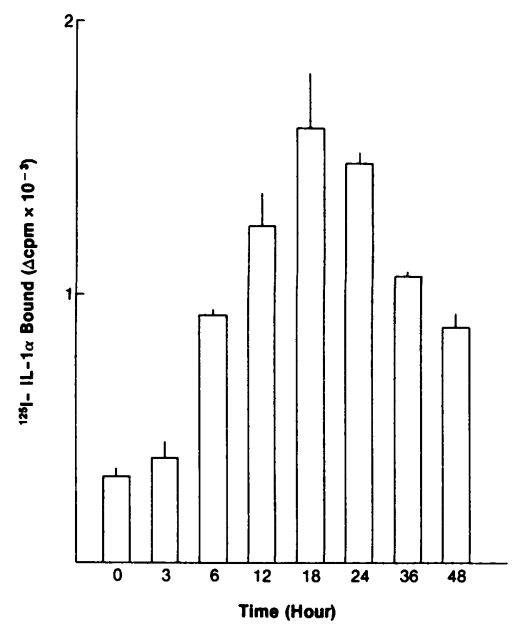

Figure 2. Time course of ${ }^{125}$ I-IL $1 \alpha$ binding to $\mathrm{PGE}_{2}$-treated fibroblasts. Fibroblasts (confluent state in $35-\mathrm{mm}$ culture dish) were incubated with $\mathrm{PGE}_{2}$ (1 $\left.\times 10^{-6} \mathrm{M}\right)$ as indicated The specific ${ }^{125}$ I-IL $1 \alpha$ binding at $14 \mathrm{ng} / \mathrm{ml}$ of ${ }^{125}$ I-labeled ligand to treated cells was determined. Nonspecific binding, defined as the amount of ${ }^{125}$ I-IL $1 \alpha$ bound to cells in the presence of $2 \mu \mathrm{g} / \mathrm{ml}$ of human recombinant IL $1 \alpha$, was subtracted from total binding to yield specific binding.

\section{Discussion}

Down-regulation of receptors by their ligands is commonly observed for hormones and cytokines including epidermal growth factor (EGF) (9), insulin (10), and IFN (11). Rapid down-regulation of IL $1 R$ expression by IL 1 has also been reported for the human LGL cell line YT (3), the murine T cell line, EL4, and the fibroblast cell line, Swiss 3T3, (5). We previously reported that a brief, 3-h incubation of YT cells with IL 1 down-regulates IL $1 R$ expression and IL 1 binding returns to normal levels by $16 \mathrm{~h}$ at $37^{\circ} \mathrm{C}$ after removal of IL 1 from the culture media. Similarly, exposure of normal human fibroblasts to IL 1 initially down-regulates IL $1 R$, and is followed by up-regulation of IL $1 R$ expression. The phenomenon of ligand-dependent induction of specific receptors has been demonstrated to occur at the level of transcription or at the protein level in the case of EGF $(12,13)$, growth hormone $(14)$, prolactin (15), insulin (16), and IL 2 (17). On the other hand, the synthesis of the receptor for low density lipoprotein has been reported to be inhibited by ligand binding (18). The basis for the effect of IL 1 on IL 1 Rene expression remains to be established.

Many reports have demonstrated the regulatory role of cAMP on gene expression (19-23). For example, forskolin and cAMP analogues enhanced the expression of low- and high-affinity IL 2 receptors on YT cells and T cell lines (24). Both

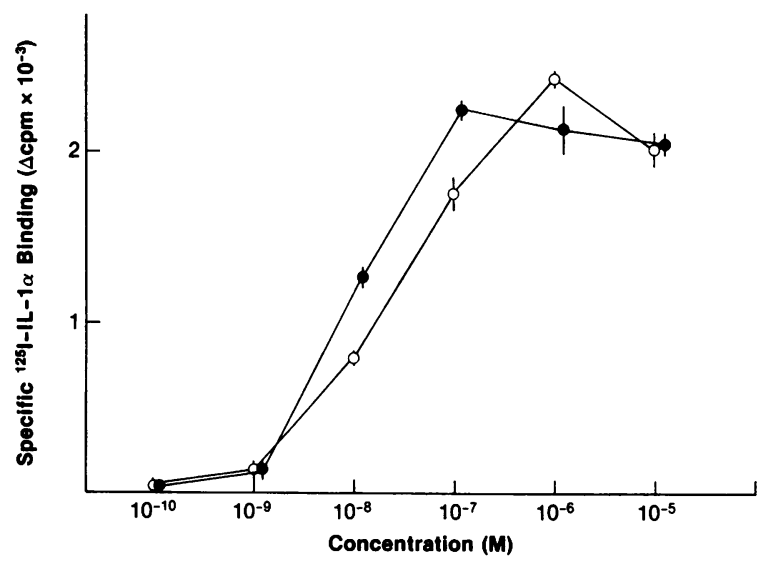

Figure 3. Effects of prostaglandins on specific ${ }^{125} \mathrm{I}-\mathrm{IL} 1 \alpha$ binding on human fibroblasts. Fibroblasts were incubated in culture media in the presence of varying concentrations of $P G E_{1}$ and $P G E_{2}$. After culture for $24 \mathrm{~h}$ at $37^{\circ} \mathrm{C}$, specific binding of ${ }^{125} \mathrm{I}-\mathrm{IL} 1 \alpha$ was determined. The level of background binding was $483 \pm 19 \mathrm{cpm}$, which was subtracted from the data shown here. $\bullet, \mathrm{PGE}_{1} ; 0, \mathrm{PGE}_{2}$. 

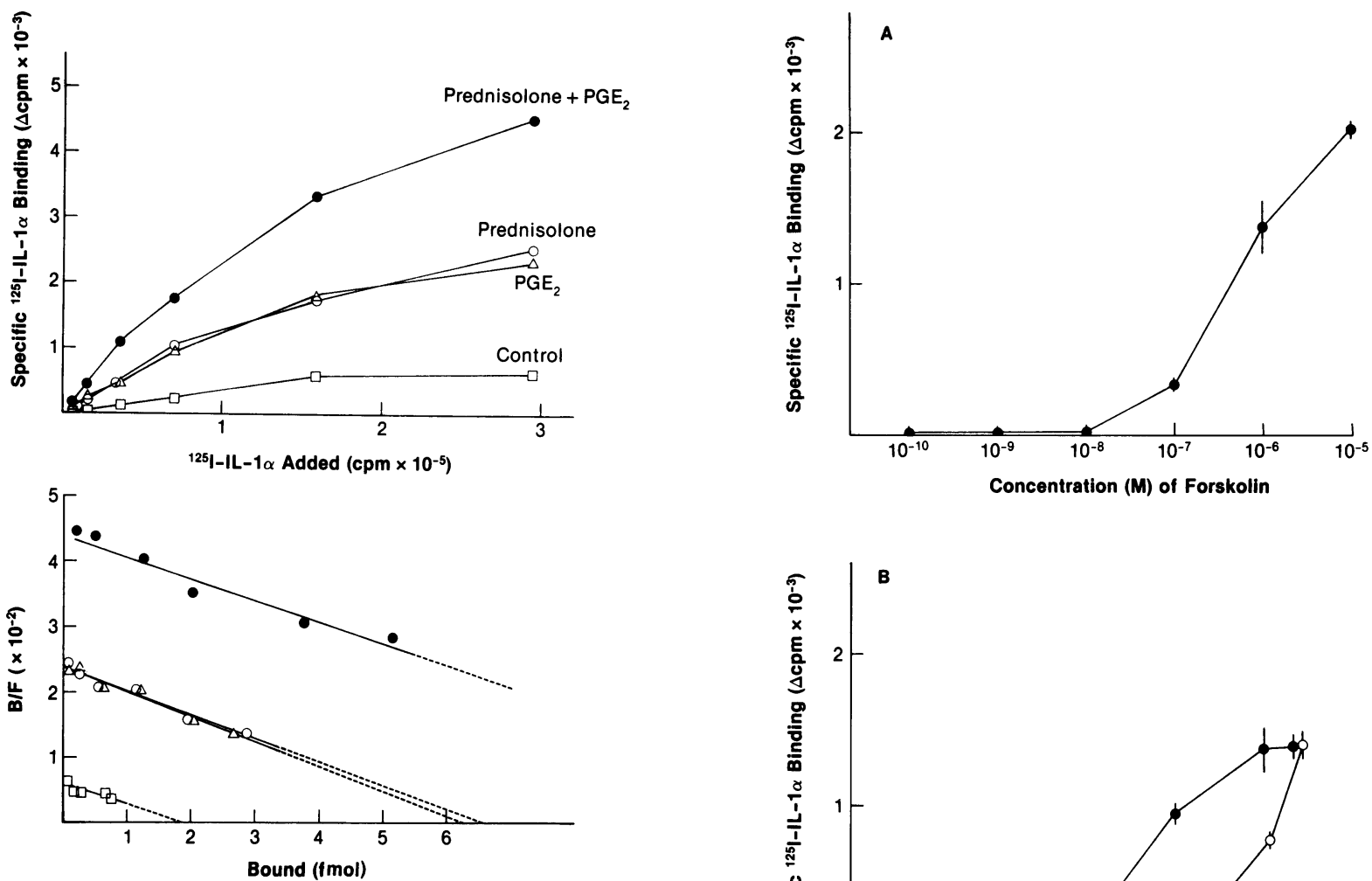

Figure 4. Specific binding of ${ }^{125}$ I-IL $1 \alpha$ to fibroblasts and Scatchard plot analysis. Fibroblasts $\left(7 \times 10^{5} / 35\right.$-mm culture dish) were incubated in culture media ( $\square$ ), in the presence of $1 \times 10^{-6} \mathrm{M}$ of $\mathrm{PGE}_{2}$ $(\Delta)$ or $1 \times 10^{-6} \mathrm{M}$ of prednisolone (O) or the combination of $\mathrm{PGE}_{2}$ and prednisolone (๑) for $24 \mathrm{~h}$. Subsequently, the cells were incubated with various dilutions of ${ }^{125} \mathrm{I}-\mathrm{IL} 1 \alpha\left(4.9 \times 10^{7} \mathrm{cpm} / \mu \mathrm{g}\right)$ for $1 \mathrm{~h}$ at $4^{\circ} \mathrm{C}$. Nonspecific binding was estimated in the presence of 140 times excess of cold recombinant IL $1 \alpha$.

cAMP-dependent protein kinase (A-kinase) and calciumphospholipid dependent protein kinase (C-kinase) (25) can also activate IL $2 \mathrm{R}$ expression in the course of lymphocyte activation. However, phorbol esters, potent activators of C-kinase, could not modulate IL $1 \mathrm{R}$ expression on fibroblasts, PBMC, and YT cells (data not shown), arguing against the involvement of C-kinase system in up-regulating IL $1 \mathrm{R}$ expression. Since forskolin, a reversible activator of adenylate

Table II. Effects of $P G E_{2}$ and Glucocorticoid on the Induction of IL 1 Receptor Expression by PBMC

\begin{tabular}{lc}
\hline \multicolumn{1}{c}{ Treatment } & ${ }^{125} \mathrm{I}-\mathrm{IL} 1$ bound \\
\hline & cpm mean $\pm S D / 10^{7}$ cell \\
Medium alone & $266 \pm 71$ \\
Indomethacin $\left(2 \times 10^{-6} M\right)$ & $328 \pm 32$ \\
$\mathrm{PGE}_{2}\left(10^{-6} M\right)$ & $1,529 \pm 67$ \\
$\mathrm{PGE}_{2}+$ indomethacin & $1,472 \pm 183$ \\
Prednisolone $\left(10^{-6} M\right)$ & $4,763 \pm 143$ \\
Prednisolone + indomethacin & $5,019 \pm 296$
\end{tabular}

PBMC $\left(1 \times 10^{7}\right.$ cells $)$ were cultured for $6 \mathrm{~h}$ at $37^{\circ} \mathrm{C}$ with $\mathrm{PGE}_{2}\left(10^{-6}\right.$ $\mathrm{M})$ or prednisolone $\left(10^{-6} \mathrm{M}\right)$ with or without indomethacin (2 $\times 10^{-6} \mathrm{M}$ ). Cells were subsequently harvested and specific binding of ${ }^{125} \mathrm{I}-\mathrm{IL} 1$ was determined as described in Methods.

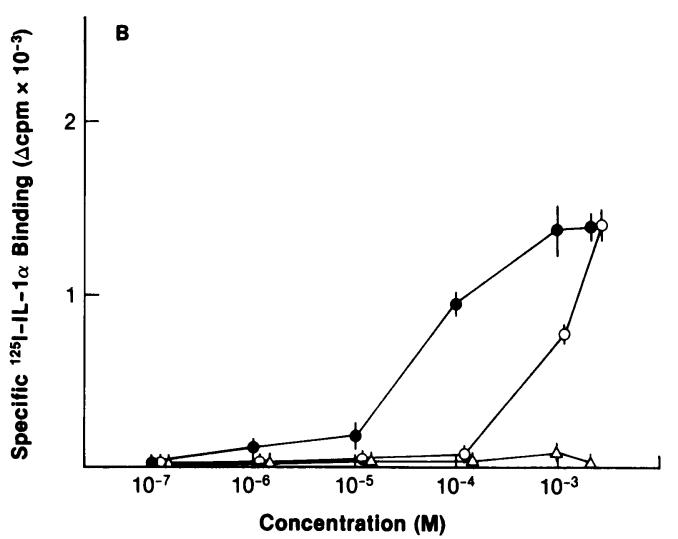

Figure 5. Effects of forskolin and CAMP on specific ${ }^{125} \mathrm{I}-\mathrm{IL} 1 \alpha$ binding on fibroblasts. The cells were incubated at $37^{\circ} \mathrm{C}$ with various concentrations of $(A)$ forskolin or $(B)$ several analogues of cAMP. After incubation for $24 \mathrm{~h}$, specific binding of ${ }^{125} \mathrm{I}$-IL ta was determined. The background binding of $483 \pm 11$ and $311 \pm 15 \mathrm{cpm}$ for the forskolin experiment and the CAMP analogues experiment, respectively were subtracted from the data shown here. ๑, dibutyryl cAMP; o, 8-Br cAMP; $\triangle$, dibutyryl cGMP.

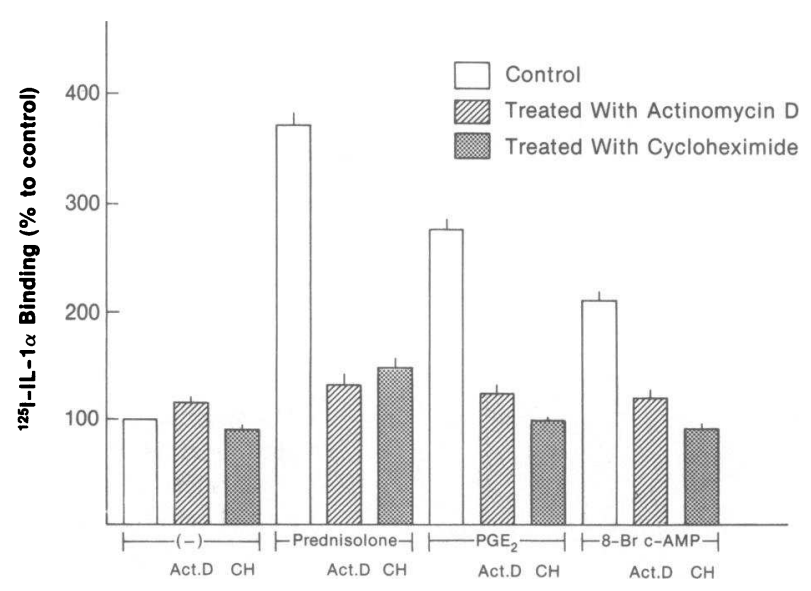

Figure 6. Effects of metabolic inhibitors on the induction of IL $1 R$ expression by glucocorticoid, $\mathrm{PGE}_{2}$, and cAMP. Fibroblasts were incubated with $3.5 \mu \mathrm{g} / \mathrm{ml} \mathrm{CH}$ or $1 \mu \mathrm{g} / \mathrm{ml}$ Act. D for $12 \mathrm{~h}$ in the presence or absence of prednisolone $\left(1 \times 10^{-6} \mathrm{M}\right), \mathrm{PGE}_{2}\left(1 \times 10^{-6} \mathrm{M}\right)$, or 8-Br cAMP $\left(1 \times 10^{-3} \mathrm{M}\right)$. Bars, mean percent (and indicated SD) of the total ${ }^{125}$ I-IL $1 \alpha$ binding to untreated control cells. $\square$, control; 四, treated with Act. D; $\square$, treated with $\mathrm{CH}$. 
cyclase, and analogues of cAMP-induced IL $1 \mathrm{R}$ expression on fibroblasts, the A-kinase system is probably involved in IL 1 -induced IL $1 \mathrm{R}$ expression.

We have previously reported the up-regulation of IL $1 R$ expression by GC on selected cell types (human peripheral B lymphocytes and fibroblasts, but not on $\mathrm{T}$ lymphocytes, monocytes, or neutrophils (4). The induction of de novo synthesis of IL $1 \mathrm{R}$ on B cells by GC is rather unexpected, because GC are well known to suppress both IL 1 production $(26,27)$ and effects of IL 1 on T cells (28), which presumably contribute to the suppressive effects of GC on inflammation and immunity. However, it has also clearly documented that GC stimulates in vitro polyclonal immunoglobulin production by PBMC (29), which may be based on the induction of functional IL $1 R$ on B cells (4). These divergent effects of $G C$ led us to propose that GC may use this mechanism to favor humoral immunity at the expense of cell-mediated immunity (4).

Prostaglandins appear to have analogous effects to GC on IL $1 \mathrm{R}$ expression. PG induce two- to threefold increases in the expression of IL $1 \mathrm{R}$ on fibroblasts and sixfold increases on PBMC. However, prostaglandins, like GC, also suppress the production of IL 1 (30), inhibit the effects of IL 1 on T lymphocytes (31), suppress Ia antigen expression of macrophages (26), inhibit macrophage cytotoxicity (32), and reduce cellular immune reactions. In contrast, conflicting data have been reported concerning the effect of $\mathrm{PGE}_{2}$ on $\mathrm{B}$ lymphocytes. Although prostaglandins suppress B cell proliferation (33), both $\mathrm{PGE}_{2}$ and $\mathrm{CAMP}$ analogues were reported to be able to synergize effectively with IL 1 and IL 2 to induce B cell maturation and antibody production (34). Thus, prostaglandins, by inducing IL 1 R on B lymphocytes, may also favor humoral immunity at the expense of cellular immunity.

The interactions of prostaglandins and IL 1 on fibroblasts are also complex. Prostaglandin mediates some of the effects of IL 1 on some cell types. For example, we have previously reported that the augmentation of human monocyte cytotoxicity by IL 1 is mediated by endogenous production of PGE (35). IL 1 stimulation of plasminogen activator production by human synovial fibroblasts is also said to be mediated by endogenous PGE production (36). In addition to mediating some of the effects of IL 1, PGE can also further promote the effects of IL 1 indirectly by inducing expression of IL 1 receptors on fibroblasts. The physiological role of IL 1 receptor induction on fibroblasts may be to promote wound healing.

Multiple interactions can potentially occur between IL 1, prostaglandins, and GC in vivo. Administration of IL 1 induces increased serum cortisol levels (37). IL 1 also induces the production of prostaglandins by many cell types (35). Inhibition of prostaglandin and IL 1 production by GC may counteract some of these effects. We have shown that both PGE and GC induce IL $1 R$ expression by fibroblasts and PBMC. Since PGE and GC induce IL $1 R$ expression in an additive manner and indomethacin did not block GC-induced IL $1 \mathrm{R}$ expression, the pathways are probably distinct. Overall, these data suggest that IL 1, prostaglandins, and GC can influence each others' production and effects in both an agonistic and antagonistic manner.

\section{Acknowledgments}

We gratefully acknowledge Dainippon Pharmaceutical Company, Ltd. (Osaka, Japan) for providing recombinant human IL $1 \alpha$. We thank Dr.
C. Faltynek for critical review of this manuscript and Ms. B. Danner and Ms. B. Unger for their editorial assistance in the preparation of this paper.

\section{References}

1. Dower, S. K., S. R. Kronheim, C. J. March, P. J. Conlon, T. P. Hopp, S. Gillis, and D. L. Urdal. 1985. Detection and characterization of high affinity plasma membrane receptors for human interleukin 1 . J. Exp. Med. 162:501-515.

2. Matsushima, K., T. Akahoshi, M. Yamada, Y. Furutani, and J. J. Oppenheim. 1986. Properties of a specific interleukin 1 (IL-1) receptor on human Epstein Barr Virus-transformed B lymphocytes: identity of the receptor for IL- $1 \alpha$ and IL-1 $\beta$. J. Immunol. 136:44964502.

3. Matsushima, K., J. Yodoi, Y. Tagaya, and J. J. Oppenheim. 1986. Down-regulation of interleukin 1 (IL-1) receptor expression by IL-1 and fate of internalized ${ }^{125}$ I-labeled IL- $1 \beta$ in a human large granular lymphocyte cell line. J. Immunol. 137:3183-3188.

4. Akahoshi, T., J. J. Oppenheim, and K. Matsushima. 1988. Induction of high affinity interleukin 1 receptor on human peripheral blood lymphocytes by glucocorticoid hormones. J. Exp. Med. 167:924-936.

5. Mizel, S. B., P. L. Kilian, J. C. Lewis, K. A. Paganelli, and R. A. Chizzonite. 1987. The interleukin 1 receptor. Dynamics of interleukin 1 binding and internalization in $\mathrm{T}$ cells and fibroblasts. J. Immunol. 138:2906-2912.

6. Zucali, J. R., C. A. Dinarello, D. J. Oblon, M. A. Gross, L. Anderson, and R. S. Weiner. 1986. Interleukin 1 stimulates fibroblasts to produce granulocyte-macrophage colony-stimulating activity and prostaglandin $\mathrm{E}_{2}$. J. Clin. Invest. 77:1857-1863.

7. Elias, J. A., K. Gustilo, W. Baeder, and B. Freundlich. 1987. Synergistic stimulation of fibroblast prostaglandin production by recombinant interleukin 1 and tumor necrosis factor. J. Immunol. 138:3812-3816.

8. Seaman, K. B., W. Padgett, and J. W. Daly. 1981. Forskolin: unique ditepene activator of adenyl cyclase in membrane and intact cells. Proc. Natl. Acad. Sci. USA. 78:3363-3367.

9. Carpenter, G., and S. Cohen. 1976. ${ }^{125} \mathrm{I}$-labeled human epidermal growth factor. Binding, internalization, and degradation in human fibroblasts. J. Cell Biol. 71:159-171.

10. Schlessinger, J., Y. Shechter, M. C. Willingham, and I. Pastan. 1978. Direct visualization of binding, aggregation, and internalization of insulin and epidermal growth factor on living fibroblastic cells. Proc. Natl. Acad. Sci. USA. 75:2659-2663.

11. Branea, A. A., C. R. Faltynek, S. B. D'Alessandro, and C. Baglioni. 1982. Interaction of interferon with cellular receptors: internalization and degradation of cell-bound interferon. J. Biol. Chem. 257:13291-13296.

12. Kudlow, J. E., C. Y. Mark Cheung, and J. D. Bjorge. 1986. Epidermal growth factor stimulates the synthesis of its own receptor in a human breast cancer cell line. J. Biol. Chem. 261:4134-4138.

13. Clark, A. J. L., S. Ishii, N. Richert, G. T. Merlino, and I. Pastan. 1985. Epidermal growth factor regulates the expression of its own receptor. Proc. Natl. Acad. Sci. USA. 82:8374-8378.

14. Baxter, R. C., Z. Zaltsman, and J. R. Turtle. 1984. Rat growth hormone (GH) but not prolactin (PRL) induces both GH and PRL receptors in female rat. Endocrinology. 114:1893-1901.

15. Manni, A., M. J. Chambers, and O. H. Pearson. 1978. Prolactin induces its own receptors in rat liver. Endocrinology. 103:2168-2171.

16. Rouiller, D. G., and P. Gorden. 1987. Homologous down-regulation of the insulin receptor is associated with increased receptor biosynthesis in cultured human lymphocytes (IM-9 line). Proc. Natl. Acad. Sci. USA. 84:126-130.

17. Reem, G. H., and N. H. Yeh. 1984. Interleukin 2 regulates expression of its receptor and synthesis of gamma interferon by human T lymphocytes. Science (Wash. DC). 225:429-430. 
18. Russell, D. W., T. Yamamoto, W. J. Schneider, C. J. Slaughter, M. S. Brown, and J. L. Goldstein. 1983. cDNA cloning of the bovine low density lipoprotein receptor: feedback regulation of a receptor mRNA. Proc. Natl. Acad. Sci. USA. 80:7501-7505.

19. Maurer, R. A. 1981. Transcriptional regulation of the prolactin gene by ergocryptine and cyclic AMP. Nature (Lond.). 294:94-97.

20. Lamers, W. H., R. W. Hanson, and H. M. Meisner. 1982. cAMP stimulates transcription of the gene for cytosolic phosphoenolpyruvate carboxykinase in rat liver nuclei. Proc. Natl. Acad. Sci. USA. 79:5137-5141.

21. Lewis, E. J., A. W. Tank, N. Weiner, and D. M. Chikaraishi. 1983. Regulation of tyrosine hydroxylase mRNA by glucocorticoid and cyclic AMP in a rat pheochromocytoma cell line. J. Biol. Chem. 258:14632-14637.

22. Montminy, M. R., K. A. Sevarino, J. A. Wagner, G. Mandel, and R. H. Goodman. 1986. Identification of a cyclic-AMP-responsive element within the rat somatostatin gene. Proc. Natl. Acad. Sci. USA. 83:6682-6686.

23. Yoshikawa, K., and S. L. Sabol. 1986. Glucocorticoids and cyclic AMP synergistically regulate the abundance of preproenkephalin messenger RNA in neuroblastoma-glioma hydride cells. Biochem. Biophys. Res. Commun. 139:1-10.

24. Narumiya, S., M. Hirata, T. Nanba, T. Nikaido, Y. Taniguchi, Y. Tagaya, M. Okada, H. Mitsuya, and J. Yodoi. 1987. Activation of interleukin 2 receptor gene by forskolin and cyclic AMP analogues. Biochem. Biophys. Res. Commun. 143:753-760.

25. Shackelford, D. A., and I. S. Trowbridge. 1984. Induction of expression and phosphorylation of the human interleukin 2 receptor by a phorbol diester. J. Biol. Chem. 259:11706-11712.

26. Snyder, D. S., and E. R. Unanue. 1982. Corticosteroids inhibit murine macrophage Ia expression and Interleukin 1 production. $J$. Immunol. 129:1803-1805.

27. Lew, W., J. J. Oppenheim, and K. Matsushima. 1988. Analysis of the suppression of interleukin $1-\alpha$ and $\beta$ production in human peripheral blood mononuclear adherent cells by a glucocorticoid hormone. J. Immunol. 140:1895-1902.

28. Gery, I., W. R. Benjamin, S. Jones, and R. B. Nussenblatt. 1983. Cyclosporine selectively inhibits certain mitotic responses of thymocytes. Transplant. Proc. 15:2311-2314.

29. Grayson, J., N. J. Dooley, I. R. Koski, and R. M. Blaese. 1981. Immunoglobulin production induced in vitro by glucocorticoid hormones. J. Clin. Invest. 68:1539-1547.

30. Knudsen, P. J., C. A. Dinarello, and T. B. Strom. 1986. Prostaglandins posttranscriptionally inhibit monocyte expression of interleukin 1 activity by increasing intracellular cyclic adenosine monophosphate. J. Immunol. 137:3189-3194.

31. Gualde, N., and J. S. Goodwin. 1982. Effects of prostaglandin $E_{2}$ and preincubation of lectin-stimulated proliferation of human $T$ cell subsets. Cell. Immunol. 70:373-379.

32. Taffet, S. M., and S. W. Russell. 1981. Macrophage-mediated tumor killing: regulation of expression of cytolytic activity by prostaglandin E. J. Immunol. 126:424-427.

33. Coffey, R. G., and J. W. Hadden. 1985. Neurotransmitters, hormones, and cyclic-nucleotides in lymphocyte regulation. Fed. Proc. 44:112-117.

34. Hoffmann, M. K., K. M. Gilbert, J. A. Hirat, and M. Scheid. 1987. An essential role for interleukin 1 and a dual function for interleukin 2 in the immune response of murine B lymphocytes to sheep erythrocytes. J. Mol. Cell. Immunol. 3:29-36.

35. Onozaki, K., K. Matsushima, E. S. Kleinerman, T. Saito, and Joost J. Oppenheim. 1985. Role of Interleukin 1 in promoting human monocyte-mediated tumor cytotoxicity. J. Immunol. 135:314-320.

36. Mochan, E., J. Uhl, and R. Newton. 1986. Evidence that interleukin-1 induction of synovial cell plasminogen activator is mediated via prostaglandin $\mathrm{E}_{2}$ and c-AMP. Arthritis Rheum. 29:1078-1084.

37. Woloski, B. M. R. N., E. M. Smith, W. J. Meyer III, G. M. Fuller, and J. E. Blalock. 1985. Corticotropin-releasing activity of monokines. Science (Wash. DC). 230:1035-1037. 